\title{
P2P lending's business models, risks and regulation
}

\section{Hang Yin}

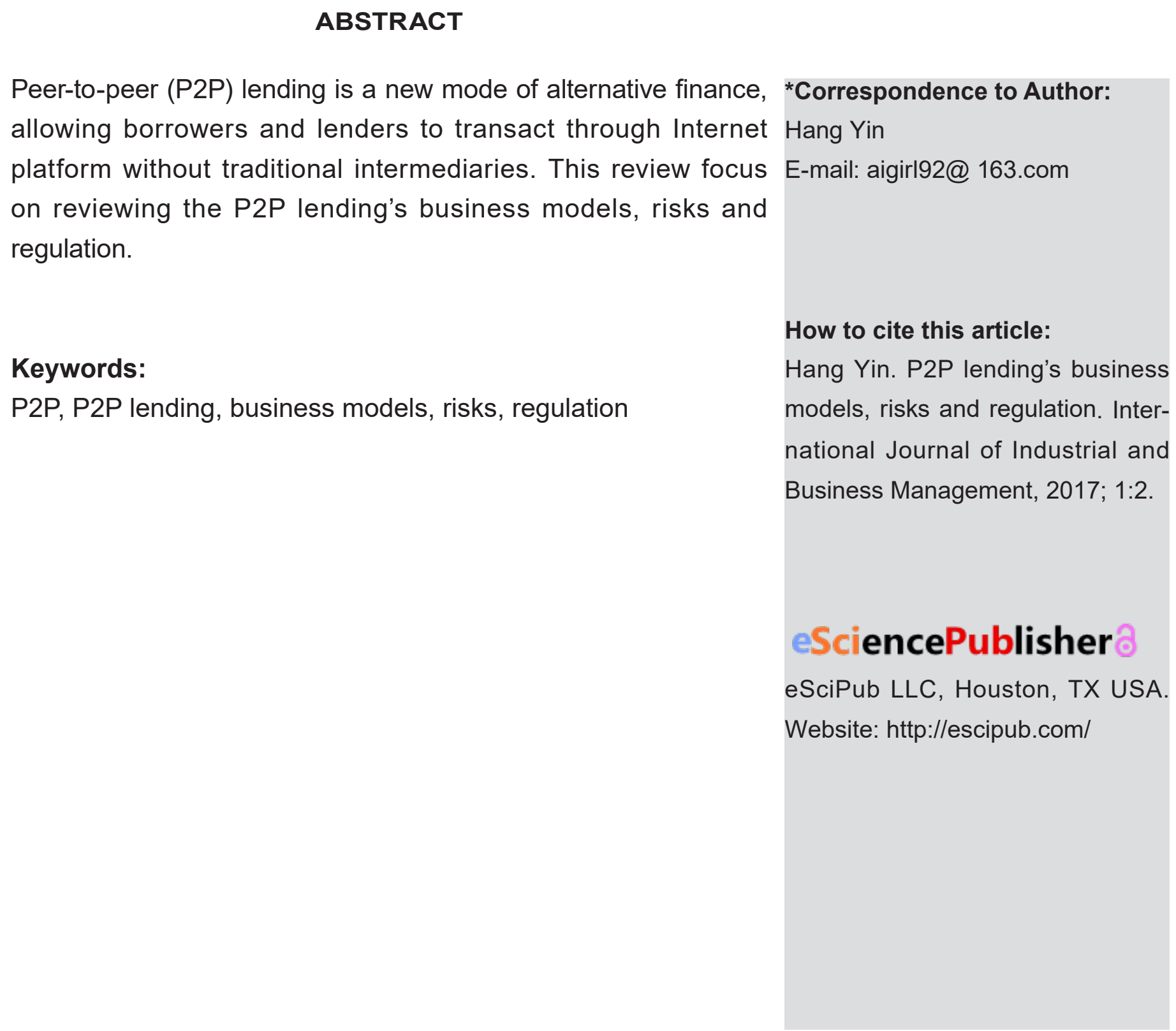


Peer-to-peer (P2P) lending is a new mode of alternative finance, allowing borrowers and lenders to transact through Internet platform without traditional intermediaries. This review focus on reviewing the P2P lending's business models, risks and regulation.

\section{P2P lending's business models}

Verstein (2008) indicated that P2P lending could be divided into P2P exchanges and loan facilitators. P2P exchanges match borrowers and lenders through an e-commerce format, and loan facilitators help the two sides to establish a lending relationship. $\mathrm{He}$ also concluded P2P lending platforms of Prosper, Lending Club, Zopa, and Kiva's business models, explaining the reasons for $\mathrm{P} 2 \mathrm{P}$ lending's high transaction efficiency. Ashta and Assadi (2009) divided P2P lending's business models into four categories, small loans, social investing, commercial lending, and social lending. ACCA (2015) classified China's P2P lending business models into online, offline, online \& offline, and pooling \& tranching modes. Additionally, Milne and Parboteeah (2016) compared P2P lending business with conventional banking business, stating P2P lending's strengths over banks to attract borrowers and lenders. From above literature, it can be seen that P2P lending models in China are more complex than the US and UK's.

\section{P2P lending's risks}

Klafft (2008) revealed the information asymmetry risk and credit risk in $\mathrm{P} 2 \mathrm{P}$ lending. Freedman and Jin (2008) also pointed out that P2P lending has information asymmetry problem because of the anonymous pattern. Furthermore, Weiss et al. (2010) emphasized the adverse selection risk from information asymmetry. Ye (2014) analyzed the P2P lending risks for different types of models in China, concluded common risks for all models and specific risks for special models. Moreover, Li et al. (2016) mainly analyzed default risk, operational risk, and policy risk in China's P2P lending market. The literature above reflects that risks of $\mathrm{P} 2 \mathrm{P}$ lending in different countries are also discrepant, as the financial environment and business models are different.

\section{P2P lending's regulation}

Current status of P2P lending regulation

The Government Accountability Office (GAO,
2011) in the United States conducted a study on peer-to-peer lending, analyzing the US's regulatory environment. This was the first time for the US government to monitor P2P lending market's development. After 5 years, the US Department of the Treasury published a white paper (Treasury, 2016) on the new opportunities and challenges in P2P lending market. As for the institutional researches, Chapman and Cutler (2014) issued a report on $\mathrm{P} 2 \mathrm{P}$ lending regulation to conclude the laws applicable to P2P lending. The institution then published this series of reports annually, updating the regulatory issues in this industry.

In the UK, the Financial Conduct Authority (FCA, 2014) published a policy statement of formal rules on P2P lending regulation in March 2014 from a macro angel. FCA then constantly monitored the businesses and regulatory situation in P2P lending industry, carrying out a review report in 2015 (FCA, 2015), and a new policy statement in 2016 (FCA, 2016) on changes to regulatory rules. As to the micro level of UK's P2P lending regulation, P2PFA issued ten operating principles to focus on the specific details of platform operation (P2PFA, 2013). P2PFA also updated its rules and principals for P2P lending platforms every year to accommodate the industry's evolvement.

In China, the central bank published a Financial Stability Report that covered a special topic on Development and Oversight of Internet Finance in April 2014 (PBC, 2014), proposing the bottom line of P2P lending industry. The Guidelines on Promoting the Healthy Development of Internet Finance (the Guidelines) issued by the PBC and other nine ministries and commissions in July 2015 (PBC, 2015) also obeyed the logic of bottom line regulation. Next, CBRC along with other three ministries and commissions jointly released the Interim Administrative Measures for the Business Activities of Online Lending Information Intermediary Institutions (the Draft Measures) on 28 December 2015 (CBRC, 2015), asking for comments publicly within an 18-month transitional period. This Draft Measures is considered to be a landmark for P2P lending regulation in China. Another milestone is the China Internet Finance Association (CIFA) established in March 2016, complementing the P2P lending 
regulatory system.

\section{Comments on P2P lending regulatory sys- tems}

Verstein (2011) pointed out that SEC's misregulation made P2P lending riskier and costly mainly because of formalistic registration and redundant mandatory disclosures. Slattery (2013) also argued that SEC regulation created high compliance costs, barriers to entry and more risks to consumers. Ridley (2016) commented on UK's 2014 crowdfunding regulation and concluded that the new regulation with single regulator provided more credibility but lower costs and would lead to more confidence. As China's regulatory rules were newly introduced, there is very few literature about it.

\section{Recommendations for $\mathrm{P} 2 \mathrm{P}$ lending regula- tion}

Verstein (2011) and Slattery (2013) both proposed to consider CFPB as a better regulator in the US to protect lenders and borrowers as well as let the industry evolve. Verstein maintained that the CFPB could address some customer needs that the SEC has failed to do, such as the misrepresentation problem and consumer complaints problem. Slattery believed that the CFPB could simplify the quagmire of consumer protection law, and could promote innovation. However, Chaffee et al. (2012) argued that a multi-agency regulatory approach would be better for the US, cohering P2P lending regulation to traditional lending regulation.

Regarding China's P2P lending regulation, Wu and Cao (2011) advised strengthening the regulatory system by improving user identification, fund management, anti-money laundering, credit rating, and cyber security. Guan (2012) proposed to create systems of the joint conference, credit rating, escrow and fund supervision. Wei (2015) proposed two options with the current regulatory system or a single regulator with a sector-wide focus. Liu (2016) applied evolutionary game theory to analyze P2P lending supervision and came to a conclusion that the regulator should strengthen the punishment force and decrease the supervision cost. Li et al. (2016) suggested that P2P lending in China should be given a specific legal status, and the regulatory body should be clarified; besides, regulation should leave room for industry innovation.

\section{References:}

ACCA. (2015). The rise of peer- to-peer lending in China: An overview and survey case study. Retrieved 21 July, 2016, from http://www.accaglobal. com/content/dam/ACCA_Global/Technical/manage/ ea-china-p2p-lending.pdf

Ashta, A., \& Assadi, D. (2009). Does social lending incorporate social technologies? The use of web 2.0 technologies in online $\mathrm{p} 2 \mathrm{p}$ lending. Working papers CEB, 9.

CBRC. (2015). The Interim Administrative Measures for the Business Activities of Online Lending Information Intermediary Institutions. Retrieved 21 July, 2016, from http://www.gov.cn/xinwen/2015-12/28/ content_5028564.htm

Chaffee, E. C., \& Rapp, G. C. (2012). Regulating Online Peer-to-Peer Lending in the Aftermath of DoddFrank: In search of an evolving regulatory regime for an evolving industry. Wash. \& Lee L. Rev., 69, 485.

Chapman and Cutler. (2014). The Regulation of Peer-to-Peer Lending A Summary of the Principal Issues (2014 Update). Retrieved 21 July, 2016, from http://www.lendacademy.com/wp-content/uploads/2014/04/Regulation-of-P2P-Lending-Chapman-and-Cutler.pdf

FCA. (2014). The FCA's regulatory approach to crowdfunding over the internet, and the promotion of non-readily realisable securities by other media. Retrieved 21 July, 2016, from http://www.fca.org.uk/ static/documents/policy-statements/ps14-04.pdf

FCA. (2015). A review of the regulatory regime for crowdfunding and the promotion of non-readily realisable securities by other media. Retrieved 21 July, 2016, from https://www.fca.org.uk/static/documents/ crowdfunding-review.pdf

FCA. (2016). FCA Handbook changes regarding the segregation of client money on loan-based crowdfunding platforms, the Innovative Finance ISA, and the regulated activity of advising on peer-to-peer agreements. Retrieved 21 July, 2016, from http:// www.fca.org.uk/static/fca/documents/policy-statements/ps16-08.pdf

Freedman, S., \& Jin, G. Z. (2008). Do social networks solve information problems for peer-to-peer lending? evidence from prosper. com.

GAO. (2011). PERSON-TO-PERSON LENDING New Regulatory Challenges Could Emerge as the Industry Grows. Retrieved 21 July, 2016, from http:// www.gao.gov/new.items/d11613.pdf 
Guan, D.B. (2012). Risks and Supervision Countermeasures on Development of P2P Network Lending in China [J]. Taiwan Agricultural Research, 5, 018.

In-text citation: (Verstein, 2008)

Klafft, M. (2008, March). Peer to peer lending: auctioning microcredits over the internet. In Proceedings of the International Conference on Information Systems, Technology and Management, A. Agarwal, R. Khurana, eds., IMT, Dubai.

Li, J., Hsu, S., Chen, Z., \& Chen, Y. (2016). Risks of P2P Lending Platforms in China: Modeling Failure Using a Cox Hazard Model. The Chinese Economy, 49(3), 161-172.

Liu, L. Peer to Peer Lending Supervision Analysis base on Evolutionary Game Theory.

Milne, A., \& Parboteeah, P. (2016). The Business Models and Economics of Peer-to-Peer Lending.

P2PFA. (2013). Peer-to-Peer Finance Association Operating Principles. Retrieved 21 July, 2016, from http://p2pfa.info/wp-content/uploads/2014/05/ P2PFA-Operating-PrinciplesV020713.pdf

PBC. (2014). China Financial Stability Report. Retrieved 21 July, 2016, from http://www.centerforfinancialstability.org/fsr/chn_fsr_201407.pdf

PBC. (2015). Credit Reference Center Operation Report (2004-2014). Retrieved 24 July, 2016, from http://www.pbccrc.org.cn/zxzx/zxzs/201508/ f 4 e 2403544 c 942 cf 99 d 3c7 1 d 3 b $559236 /$ files/0e78bdbd53cf4ed39b25d886a16054c9.pdf

PBC. (2015). The Guidelines on Promoting the Healthy Development of Internet Finance. Retrieved 21 July, 2016, from http://www.gov.cn/xinwen/2015-07/18/content_2899360.htm

Ridley, D. (2015). Will New Regulation on Crowdfunding in the United Kingdom and United States Have a Positive Impact and Lead to Crowdfunding Becoming an Established Financing Technique? Statute Law Review, hmv026.

Slattery, P. (2013). Square pegs in a round hole: SEC regulation of online peer-to-peer lending and the CFPB alternative. Yale J. on Reg., 30, 233.

Treasury. (2016). Opportunities and Challenges in Online Marketplace Lending. Retrieved 21 July, 2016, from https://www.treasury.gov/connect/blog/ Documents/Opportunities_and_Challenges_in_Online_Marketplace_Lending_white_paper.pdf

Verstein, A. (2008). Peer-to-Peer Lending Update and Regulatory Considerations. Madison: Filene Research Institute. son-to-person lending. UC Davis Law Review, 45(2).

Wei, S. (2015). Internet lending in China: Status quo, potential risks and regulatory options. Computer Law \& Security Review, 31(6), 793-809.

Weiss, G. N., Pelger, K., \& Horsch, A. (2010). Mitigating Adverse Selection in P2P Lending-Empirical Evidence from Prosper. com. Available at SSRN 1650774.

Wu, X., \& Cao, Y. (2011). The Regulation Strengthening of the P2P Online Lending Platform [J]. South China Finance, 4, 009.

Ye, X.R. (2014). The Risks of China's P2P Lending Models and Related Regulations [J]. Financial Regulation Research, 3, 006.

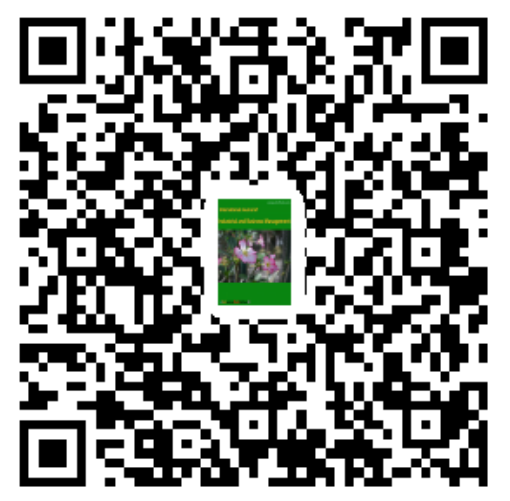

Verstein, A. (2011). The misregulation of per- 